Documents pour l'histoire du français langue étrangère ou seconde

$53 \mid 2014$

Français, anglais et allemand: trois langues rivales entre 1850 et 1945. French, English and German: three languages in competition between 1850 and 1945

\title{
French and German in British schools (1850-1945)
}

Nicola Mclelland

\section{(2) OpenEdition \\ Journals}

Édition électronique

URL : https://journals.openedition.org/dhfles/4089

DOI : $10.4000 /$ dhfles.4089

ISSN : 2221-4038

Éditeur

Société Internationale pour l'Histoire du Français Langue Étrangère ou Seconde

Édition imprimée

Date de publication : 1 décembre 2014

Pagination : 109-124

ISSN : 0992-7654

Référence électronique

Nicola Mclelland, «French and German in British schools (1850-1945) », Documents pour I'histoire du français langue étrangère ou seconde [En ligne], 53 | 2014, mis en ligne le 10 septembre 2017, consulté le 28 mai 2021. URL: http://journals.openedition.org/dhfles/4089; DOl : https://doi.org/10.4000/ dhfles.4089

Ce document a été généré automatiquement le 28 mai 2021.

(c) SIHFLES 


\title{
French and German in British schools (1850-1945)
}

\author{
Nicola Mclelland
}

\section{Introduction: An unequal competition from the very beginning}

1 Given the theme of this volume (languages "in competition"), it is worth making clear from the outset that as far as the British Isles are concerned, there was no real "competition" amongst the foreign languages, at least not in the sense of a close contest. Although German certainly did have to compete with French for attention, the competition was a very uneven one. French had, for historical reasons, always been the first foreign language in Britain. For centuries after the Norman Conquest, Britain was characterized by French-English diglossia among the elite (even French-English-Latin triglossia) and French still had the status of a lingua franca in European court circles well into the eighteenth century (Rjéoutski, Argent \& Offord 2014). I should also warn that I am a Germanist whose interest in this subject began with the history of German teaching and learning - my perspective is rather that of looking at the position of German in comparison to French, rather than an even-handed evaluation of the two. The underlying research for the detailed history of French in schools since 1850 has not yet been done ${ }^{1}$.

2 German first began to compete with French for prestige, at least, if not for numbers of learners, from the mid-eighteenth century onwards, as it was increasingly recognized as a literary language alongside French (for more detail on the period up to 1850 (McLelland in press 2015). Gebhard Wendeborn, Minister for the German chapel on Ludgate Hill, London, summed up the changing status of German compared to French in Europe of the 1770s in his Elements of German Grammar as follows:

The French, who in general are thought to be rather partial to their own productions, have lately begun to study the German language, and to think favourably of German literature; against which they formerly entertained great prejudices. Among the English the German has been hitherto very little known; but 
there is reason to expect, that within a few years, even in this country [i.e. England], so famous for the improvement and patronage of the arts and sciences, the language and the literature of the Germans will no more be looked upon with indifference. (Wendeborn 1774: VIII)

Wendeborn's grammar was reviewed in 1775 in the Critical Review (reprinted in Boehning 1977, I: 266), and the reviewer commented, "As German literature is at present of much greater consequence than is commonly apprehended, we join with the author in wishing, that it were more attended to, and that this Grammar may be an inducement and a help to the study of it, for at present we know scarce anything of it, excepting through the medium of French translations." Wendeborn's Elements of German Grammar (1774) was, to judge by the title, modelled on Louis Chambaud's Elements of the French Language (1762). Wendeborn also announced his intention to publish a grammar with exercises like those of Chambaud. The fact that Wendeborn used a French textbook as a model for his own German one is typical of textbook history in Britain. Many textbooks of German for English-speaking learners have been based on versions that were first produced for learners of French and proved successful. For example, Henry Weston Eve's School German Grammar (1880) was "uniform with the Wellington College French Grammar" that he had published with F. de Baudiss in 1870, as the title page proclaimed. Eugène-Fasnacht, author of a Progressive German Course, had already published a Progressive French Course. Other cases of German textbooks based on earlier French versions are Otto (1890), Bally (1896), Trotter (1898), Rippmann (1899), Siepmann (1900, 1912), Atkins (1905), Leather (1932), and Ireland (1935). French, rather than German, then, was the field in which new approaches to teaching were most likely to be tried out first. As far as I am aware, there are no exceptions to this rule (where a French text follows a German model) before the 1930s, when German enjoyed a resurgence (section 4. below): judging by the holdings in COPAC, Stockton (1936) published his passages for practising German composition before the French equivalent (1938), and Lentz's German vocabulary: the 3500 most useful words arranged in connected groups suitable for translation, conversation, and free composition in University Matriculation, Leaving Certificate, and similar examinations (1945?) seems to have preceded the equivalent French text (1969).

\section{French and German in schools in the $18^{\text {th }}$ and $19^{\text {th }}$ centuries}

4 In the eighteenth century, while French was widely taught in private schools catering to the emerging middle classes, German seems to have been taught only in the so-called Dissenting Academies of non-conformist Protestant groups, where modern languages were taught alongside Latin, Greek, English, Mathematics and a science; the number of these and similar schools increased after 1779, when non-conformists were legally allowed to be teachers (Ortmanns 1993: 21, following Watson 1921: 694). Many other pupils would have learnt German with a private tutor. The position of German compared to French was further enhanced from the 1840 s by the royal example of Queen Victoria, who employed a German governess for her children, so that from the 1840s "an increasing number of well-to-do families in England wanted their children to be taught German by a native speaker (Hardach-Pinke 2000: 25). 
5 From the 1830s, French and German began to be offered in the emerging major Public Schools; the first to offer German may have been the newly founded University College School (founded as part of University College London, established in 1826). Its prospectus, issued in 1830, indicated that boys would "enter the German class" as soon as they were "sufficiently master of the French language"; the study of German was "introduced for the specific purpose of enabling the pupil to avail himself of the valuable assistance afforded by the labours of German Philologists towards the right study of Classical Literature". Five hours a week were to be devoted to French and German combined in the third to sixth classes (Usher, Black-Hawkins \& Carrick 1981: 13). Shrewsbury (1837), Harrow (1839) and, in the 1840s, Winchester, King's School Canterbury, Marlborough and Uppingham all followed suit (Proescholdt 1991: 95; Ortmanns 1993: 28). At Rugby, under the headship of Thomas Arnold, French and German were apparently even compulsory for pupils not taking a science (Ortmanns 1993: 27; Hope Simpson 1967: 7).

6 The 1850s saw French and German find their place in public examinations. In 1855 candidates could offer French and German both for Civil Service examinations and for admission to the Military Academy at Woolwich. For the period 1886 to June 1888, 49 of 360 successful candidates passed in German, 94 in French; for the period November 1888-1890, 125 out of a total of 325 successful candidates passed in German, 254 in French. In June 1893, only 3 candidates took German as an obligatory subject, while 40 took French (Ortmanns 1993: 53-54). Despite the fact that candidates taking French far outnumbered those taking German, German was in fact felt to be more useful:

For the Officer who means to devote himself to scientific research, German is most important. French appears to me to have no such claims. Useful as it is on the common level of life, its study as a literary language does little for the mind. Idle boys fly to French [...]. (Report 1894: 211)

7 Accordingly, German was made compulsory at Wellington Military Academy (founded 1853) by the mid-1860s (Ortmanns 1993: 31-32).

8 In 1858, French and German were included amongst the subjects for which candidates could present themselves for University of Cambridge Syndicate examinations first offered to pupils in that year, and for the equivalent Oxford examinations. ${ }^{2}$ After 1868 , many private schools adjusted their curricula in favour of modern languages and sciences (Ortmanns 1993: 30), although from 1875 onwards, the sciences in turn began to squeeze modern languages. By the 1890s, an enquiry by the Modern Language Association found that 55 of 93 "chief public schools" offered German, mostly beginning at the age of 16 (Breul 1897). On the "classical" side (those pupils targeting university), on average $25 \%$ took German, though with wide variations; while on the "modern" or commercial side, the figure, though similarly variable, rose to an average 31.4\% (Ortmanns 1993: 35). At the Oxford Local Examinations in 1895, 430 pupils attempted German at the Junior (under 16) level compared to 2.845 for French; 348 attempted it at Senior level, compared to 12,344 for French (Tables 1 and 2 from Ortmanns 1993: 34, citing Breul 1897: 829-833) - note the relatively low pass rates in the languages (with the exception of the handful of Spanish entrants) compared to the mother tongue, English. The numbers of candidates in German were, then, 15\% and 28\% respectively of the number of candidates for French Junior and Senior examinations.

9 In 1851, only $3.8 \%$ of public day schools "catering to the poorer classes" (though certainly not the poor) offered a modern language (Bayley 1989: 58). ${ }^{3}$ The higher grade 
elementary schools (i.e. schools for the older and more able pupils, up to the age of about 14 or 15, who had passed the equivalent of Year 6, the end of today's primary education) began to offer German from 1880, once it attracted government funding; French had been eligible since 1872. By 1894, the Bryce Report found that French was taught in virtually all 32 higher grade and organized science schools surveyed, catering between them to 22,480 children; but only 11 of those 32 offered German as well as French. These schools also entered children for the Oxford and Cambridge Local examinations. However, the numbers were small - of 18,449 children who took examinations in "specific" subjects in 10 London boroughs in 1885, there were only 423 passes in French, and none at all in German (Bayley 1989: 62).

\begin{tabular}{|l|l|l|}
\hline JUNIOR (under 16) & Candidates & Passed \\
\hline German & 430 & $210(49 \%)$ \\
\hline French & 2845 & $1590(56 \%)$ \\
\hline English & 3115 & $2230(72 \%)$ \\
\hline Latin & 1315 & $605(46 \%)$ \\
\hline Spanish & 4 & $4(100 \%)$ \\
\hline Total & 3226 & $2075(64 \%)$ \\
\hline
\end{tabular}

Table 1: Junior Oxford Local Examinations in 1895

\begin{tabular}{|l|l|l|}
\hline Senior (under 18) & Candidates & Passed \\
\hline German & 348 & $209(60 \%)$ \\
\hline French & 1244 & $760(61 \%)$ \\
\hline English & 3115 & $2230(72 \%)$ \\
\hline Latin & 397 & $299(75 \%)$ \\
\hline Greek & 112 & $59(53 \%)$ \\
\hline Spanish & 3 & $3(100 \%)$ \\
\hline
\end{tabular}

Table 2: Senior Oxford Local Examinations in 1895

Meanwhile, the Educational Annual of 1891 (cited by Ortmanns 1993: 38) reported that out of 794 secondary schools of various types, 217 taught German (345 taught French, 6 Spanish and 4 Italian). In higher elementary schools, of 71,057 children taking a specific (optional) subject (who already made up only 1.8 to $3.7 \%$ of all pupils at these schools), 225 took either French or German (the breakdown between languages is not known). In 1866 , of 58 Scottish schools, with a total of 14,079 pupils, 29 schools offered German, to 
a total of 554 pupils, compared to 53 schools offering French to a total of 2,682 pupils; all schools offered Latin, taken by a total of 3,529 pupils (Ortmanns 1993: 84). In Glasgow secondary schools, the number of pupils who passed German as a "specific" subject rose from 1 in 1881, to 58 in 1885, 220 in 1895, and 269 by 1899, but the number always stood at about one tenth of the number who passed French.

Although there was a perceived need for French and German for commercial purposes, this was not reflected at all in the types of examinations for which pupils were prepared, nor indeed in the Elementary Code which governed the curriculum of such schools (Bayley 1989: 62). From 1888 to the mid-1890s the Cambridge Syndicate offered a Commercial Certificate including a foreign language element, but it was not a success. In the first year, only 8 of 49 candidates were awarded Commercial Certificates (Report 1889: 5), and the number of entrants had declined to 8 by 1893. In German, the examiners lamented in their report that "the most ordinary rules of German grammar seemed to be unknown to most of the candidates [...]. No candidate was able to write a German business-letter on a given subject" (ibid.: 9). "In German Conversation [not compulsory] two of the seven candidates who presented themselves passed" (ibid.:10).

\subsection{A note on French and German teaching for women and girls}

In Charlotte Brontë's novel Villette (1853 [2000]: 54), seventeen-year old Ginevra Fanshawe declares (with some hyperbole, as befits her character):

I know nothing - nothing in the world - I assure you; except that I play and dance beautifully, - and French and German of course I know, to speak; but I can't read or write them very well. Do you know they wanted me to translate a page of an easy German book into English the other day, and I couldn't do it.

Very often girls whose brothers went to public school were themselves educated entirely in the home by native-speaker governesses (in accordance with the "fancy", roundly dismissed by Bernays (1849: 100), "that languages are best learnt without a grammar"). Girls were, indeed, more likely than boys to learn both French and German because they were not expected to study Latin and Greek. Even when girls did go to school, very different expectations and patterns of education for girls and boys resulted in differing outcomes in language education. In Ireland, Fischer suggests, German was a subject for girls from the outset, in contrast to French, which was long predominantly perceived as a boys' subject (Fischer 2000: 465-466). Fischer cites some examples of teacher and pupil exchanges between Irish convent schools and their German counterparts in the very late $19^{\text {th }}$ century. ${ }^{4}$ Bernays's series of lectures at the newly founded Queen's College in 1849, a college for the training of governesses, was, however, quite possibly the first time that young women were exposed to the NeoHumanist approach to foreign language education that dominated the education of boys, with emphasis on grammar, exercises and translation. Ortmanns (1993: 38) calculated, on the basis of data in Johnson (1891) that out of 151 girls' schools investigated, 72 (47\%) had German, 95 (63\%) had French (and one Italian), compared with 217 (27\%) and 345 (43\%) out of 794 schools overall for which Johnson gives figures. Proportionally, then, French and German were more widely available in girls' schools than in boys' schools - indeed, a higher proportion of the girls' schools (47\%) offered German than the proportion of boys' schools offering French (43\%). Already in 1868, more girls took German at Senior level than did boys ( 38 girls, 25 boys), even though there were far more male candidates overall (160 girls, 218 boys). When an 
"Examination for Women" was introduced in 1869 (Schedule 1869; initially aimed at providing a qualification for governesses, from 1875 known as the Higher Local Examination, and open to men and women), it already included Italian, thus offering to women a wider range of modern language examinations than did the Junior and Senior examinations for boys and girls.

\subsection{Who taught French and German?}

Though the form-masters still taught French to the lower school, another master had come, with a degree of doctor of philology from the University of Heidelberg and a record of three years spent in a French lycée, to teach French to the upper forms and German to anyone who cared to take it up instead of Greek. (Somerset Maugham, Of Human Bondage, 1915 [2000]: 66 (chapter 16\})

In 1864, the nine big Public Schools (i.e. privately funded, fee-paying schools) in England had between them 18 teachers of modern foreign languages, compared to 48 for Latin and Greek (Ortmanns 1993: 28). To judge from Somerset Maugham's semiautobiographical account of teaching practices at a minor English Public School in the late 1880s (cited above, based on his experiences at King's School, Canterbury), any teacher at all would be expected to teach French at lower levels; for German, some kind of particular experience or competence seems generally to have been deemed necessary. For example, Henry Weston Eve (d. 1910), Headmaster of University College School from 1876 and the Dean of the College of Preceptors from 1884, was a teacher of both French and German (as well as Maths and Chemistry), having perfected his German while studying chemistry in Heidelberg; he published a number of textbooks of French and German, noted above.

However, like Eugene Oswald (1826-1912), who took up the post of assistant master at University College School in 1856 (Flood 2000: 243-244), teachers of German were generally still, as they had almost always been in the history of learning German in Britain, native speakers from Germany. Certainly two prominent proponents of the Reform Movement fall into that category: Walter Rippmann (1869-1947, who was born in Britain to German parents, and clearly brought up bilingual, since he was awarded a First Class B.A. in German by the University of London at the age of 18 , having studied for it as an external student; and Otto Siepmann (1861-1947), who moved in 1885 to Britain to a teaching post in Kent, then Inverness, before settling at Clifton College, Bristol, in 1890, where he spent the next 31 years. As the founding head of modern languages at Clifton from 1900, Siepmann reformed the curriculum radically, such that pupils had an hour of French and an hour of German daily, and "This unusual arrangement produced a steady stream of modern languages scholars destined for the universities of Oxford and Cambridge" (Whitehead 2004; McLelland 2012 for more on the life and works of Rippmann and Siepmann).

After 1918, a new controversy emerged, no doubt in part fuelled by World War I, though a Modern Languages Association sub-committee had already been appointed to look into the matter in 1913: this was the question of whether teachers and university professors of modern languages ought, by preference, to be British nationals (Bayley 1991: 16). The Modern Languages Association inquiry found that only 8 of 23 modern language professors in English universities were British. Symptomatic of the atmosphere was the resolution proposed to the General Meeting of the Modern Language Association on January 11, 1918, and reported in Modern Language Teaching 14 
(1918): 22-25 under the heading, "Who shall teach modern languages?". Mr. A. Hargreaves had proposed that "in the interests of education" (under which he also included "the formation of character") it was better to have modern languages taught "by persons of British nationality". Not surprisingly, Walter Rippmann (who had found it advisable to anglicise the spelling of his name when war broke out) objected. The exchange between Hargreaves and Rippmann (now Ripman) continued through the issues of Modern Language Teaching 14 (pp. 133, 151, 198).

\subsection{French and German as first and second foreign languages}

It seems to have been universally assumed until well into the $20^{\text {th }}$ century that pupils would not begin German until they had already taken some French. For example, we saw earlier that the University College School prospectus of 1830 indicated that boys would "enter the German class" as soon as they were "sufficiently master of the French language". Bischoff (1939: 195) presents evidence that German was always the (optional) second-learned foreign language after French in both girls' and boys' schools in Scotland at the time he was reviewing (late $19^{\text {th }}$ century to 1939). A July 1890 German examination paper at Rugby School asked pupils to supply Latin cognates and to "trace the word Apotheke in Greek, French and English", which suggests that pupils were learning German as their fourth language, and their second modern language (July 1890, Upper School German Fifth set). Both Siepmann and Rippmann (in Siepmann's Public School German Primer, ${ }^{1} 1896$, and Rippmann's First German Book, ${ }^{1} 1899$ ) assumed that users of their books would already have learnt French for some time (Siepmann 1900: VII, X; Rippmann 1917: V); Siepmann (1900: X) expected his learners to be about fourteen. For Siepmann, this meant that the reading passages in his German Primer though "simple and easy" - should not be "as childishly easy and simple as most German Books for Beginners" (ibid.: XII). However, Siepmann did later produce a Primary German Course intended for pupils a year or two younger (Siepmann 1912), and it went into three issues within its first year, suggesting that there was by this stage a market for learning German among somewhat younger pupils. Whether they would still have learnt French first is not clear.

20 In 1897, about half as many hours in the curriculum were devoted to German as to French (Ortmanns 1993: 37); and in the many sets of figures available to Ortmanns, the numbers of pupils taking German compared to those taking French in the late nineteenth century range between about a tenth (the number of pupils in Glasgow secondary schools taking German as a special subject compared to French in the 1880s) and about a quarter (the number of candidates taking German compared to French at Oxford local examination in the 1890s). In Ireland $90 \%$ of pupils took an examination in French at any level in 1912, but only $18.4 \%$ took one in German - and even this represented the high-point, the culmination of a doubling in numbers taking German between 1878 and 1899, and again between 1900 and 1910 (Fischer 2000: 464). The status of foreign languages in Ireland was in some ways and at some times very different to that in England, however, in part to do with Irish nationalism both before and under the Irish Free State. Fischer cites a 1908 commentator's remark that "To free ourselves from the intellectual control of England is the main purpose with which the study of modern languages can be recommended" (Fischer 2000: 467). German, even more than French, was adopted by this nationalist, de-anglicizing current: in one year 
(1930), 42.5\% of candidates answered their German examinations in Irish, but only 5.5\% of pupils taking French did so (Fischer 2000: 468-69).

\section{Modern foreign languages vs the Classics in the early $20^{\text {th }}$ century}

While German always competed for attention after French, the two languages were nevertheless grouped together as "modern languages", to the extent that some authors published collections of tasks that could be done in French or German. Emil Trechmann, lecturer in modern languages at the University of Sydney from 1889 to 1903, published his Passages for Translation into French and German for use in University and school classes in Sydney in 1899 , for example. ${ }^{5}$ Jointly, then, "the" modern languages were engaged in another competition - against the Classics. Despite his commitment to modern languages, even Otto Siepmann accepted that the classical languages still mattered more than French and German, at least for examination purposes. In a letter to his son Harry, who was preparing for the Rugby scholarship examination, Siepmann expressed concern that Harry was apparently not being praised as highly in Latin and Greek as he was for his work in French and German, "for your future rests on the classical languages. In Rugby you will be tested in German and French too, it is true, but Latin and Greek are the main thing" (Siepmann, letter dated $6^{\text {th }}$ February 1902). ${ }^{6}$

Nevertheless, things were changing. Karl Breul, Reader in German in Cambridge (and Schröder Professor of German there from 1910), observed in a publication originally delivered as a lecture for trainee teachers that the case for Modern Languages was well on the way to being won: "Modern Languages are at last beginning to receive in this country the attention to which the subject is entitled not only by its practical usefulness but still more by its intrinsic value as an important element in a truly liberal education" (Breul 1899: VI).

The relative strength of modern languages by the turn of the century is evident in the very fact that Breul had an audience of trainee language teachers; language teaching had become professionalized (French no longer just the province of any form-master), just as the languages had become institutionalized in schools, though they were still finding their feet in universities; the Cambridge modern languages tripos (i.e. the modern languages specialism within a Bachelor's degree at Cambridge) introduced in 1896 was the first of its kind (Paulin 2010). As Breul's remark makes clear, modern languages had won a place in the curriculum "not only" on the grounds of practical usefulness (arguably not at all - experiments in teaching 'useful' commercial language had not been a success), but "as an important element in a truly liberal education". Modern Languages as a single discipline had won its case by vying with the Classics as the key both to linguistic analysis and great literature, and thus both to developing mental rigour and to providing moral edification.

Admittedly, not everyone was fully convinced by the argument that modern languages could provide all that the Classics had done. A more sceptical view was expressed by a certain G.F. Bridge, who wrote witheringly in the Contemporary Review of 1921 that the student of modern studies "never progresses. He never goes on from literature to life" (Bridge 1921: 807). At university as at school, Bridge stated, such students' courses "consist in the acquirement of a foreign language, or two foreign languages, for 
practical purposes, the investigation of linguistic phenomena, and the reading of aesthetic literature, which, in the view of the teachers must be studied because it embodies the language at its best." Such students graduated experts in "imaginative literature", but having "never faced and tried to think out problems of philosophy, politics and ethics", as an education in the Classics - reading great thinkers on logic, philosophy, law, history, ethics - would have forced them to. University Schools of Modern Languages were "little more than nurseries for teachers" (Bridge 1921: 808). Indeed, over $80 \%$ of University College London language students entered the teaching profession, and Sir Charles Oman, professor of history at Oxford, wrote in his memoirs that "I have heard it said that this [Modern Languages at Cambridge] is the honour school for intending schoolmistresses" (cited by Phillips \& Filmer-Sankey 1993: 13).

Notwithstanding Bridge's scorn for Modern Languages graduates, the signs for the modern languages in the early twentieth century were good. The numbers of graduates in Modern Languages increased from 60 in 1904 to 200 in 1914, and to 600 by 1923 (Bayley 1991: 22). The Board of Education's Circular 826 of 1913 recommended that a second foreign language should be taken up before the third year of secondary school, and that modern languages should have equal status with the Classics and mathematics and science (ibid.: 20). ${ }^{7}$ From 1919, modern foreign languages were also weighted equally with Classics in Civil Service examinations (ibid.: 21). The ultimate victory of Modern Languages over Classics is evident in the fact that by 1926, twice as many candidates were presenting for French as for Latin in the First Examination for the School Certificate $(54,273$ candidates for French, 23,558 for Latin; ibid.).

The Leathes Report of 1918 (footnote 6) listed five reasons for learning a language: for business; for the replenishment of the national store of knowledge; for the cultivation of public awareness of foreign countries; for public service; and as an instrument of general education and culture..$^{8}$ In fact, it was the arguments about cultural value that held the most sway, while arguments resting on utility and relevance served principally to make the case for choosing modern languages ahead of dead languages, the Classics, in order to achieve the overriding aim of cultural education. It is significant that the Leathes report talked of Modern Studies rather than Modern Languages. As Benson (1907: 11) had already imagined, anticipating the CLIL movement by several decades, "The point would be that the subjects would play into each other. History could be read in French, history and geography questions could be answered in French; and the result might be that the boy might feel what he seldom feels now, the joy of mastery." 9

\section{German on the back foot}

The early decades of the twentieth century saw the continuation of very active discussions among language teaching professionals of the teaching of modern languages generally. They can be traced, for example, through the early volumes of the journal Modern Language Teaching, as well as through numerous reports (Arnold \& Waren 1900; Benson 1907; Brereton 1908; Board of Education 1912, 1928a-1930b; Collins 1934). Paradoxically, German was both at first receiving more attention than ever and yet, soon, becoming more endangered than it had been since its introduction into the curriculum a half-century earlier. German was, overall, in decline compared to French in the first three decades of the twentieth century. For the trouble with the intellectual grounds on which Modern Languages trumped the Classics, discussed above, was that 
they did not make the case for more than one foreign language. True, G.F. Bridge (1921) might argue that if the goal of teaching modern languages was to acquaint pupils with great writing, then one should relegate French poetry to the second rank and instead take German poetry and drama, which were "loftier in tone, richer and deeper in feeling" (Bridge 1921: 807-810). On the whole, however, scant time in the curriculum and the burden on the pupil pointed to the idea of focussing efforts on just one language. That language was, inevitably, French, because it already dominated, and so in a circularity that has continued to frustrate - teachers of French were most easily found. After all, inadequate teaching of German could be a serious problem: Fischer (2000: 467) cites the case of one school in Ireland in 1937 where 27 of 34 pupils from a single school failed their German examination. ${ }^{10}$

In his address to the Modern Language Association of 1907, the Association's president A.C. Benson stated, "I do not think that we can secure a firm position for German, but yet I think we can secure it for French" (Benson 1907: 16). Benson further argued:

My own belief is that, if the attention of boys were concentrated on one language, they would attain the knowledge of structure, idiom, and vocabulary that is essential to the success of the process, and instead of constructing a dreary and ugly mosaic in three practically unknown tongues, they might be receiving the benefit of a process which would at once be disciplinary and stimulating. (Benson 1907: 12)

Making all pupils habitually learn more than one language only confused the average child, Benson argued, and he discoursed entertainingly on his struggles with a group of "big boys at Eton", "industrious" but of "little intellectual capacity", who swung week by week from applying either the Greek or Latin rules for the sequence of tenses in dependent questions to both languages, according to whichever set they had had drummed into them that particular week, "the demon being cast out, and re-appearing round the corner with Satanical regularity" (Benson 1907: 10). Benson did emphasize the value to be obtained from reading in a foreign language:

It gives mental proportion, mental perspective; it shows that people of different nationalities approach subjects from different points of view; it gives largeness and breadth to the mental horizon; it corrects the insularity and self-satisfaction that is one of the worst qualities of a complacent and self-absorbed nationality; it introduces the mind to a whole range of novel ideas and emotions; it shows the different scale of qualities among the nations. (Benson 1907: 13)

Yet he opined:

I venture to believe that this is possible with a single language only, for most people, and that it is far more possible with a modern than with an ancient tongue [...]. I claim, then, that a single modern language should be made the basis of our linguistic instruction; and, though I am inclined to think that we Englishmen are more in need of the kind of message which German literature can give us: its lofty emotion, its intellectual enthusiasm, its unaffected idealism, yet I believe that French is probably the more practical choice, because of its greater variety, its more tangible imaginativeness, and its exquisite precision and delicacy of literary form. (Ibid.)

31 Further arguments in favour of French as first choice were the proximity of France, its long tradition as a language of diplomacy, and the fact that "with its moderate inflexions, it comes half-way between the purely synthetic Latin and the purely analytic English" (Benson 1907: 10). If one agreed that only one language was necessary, then, French was the obvious first choice. 

the twentieth century is evident in the frequency of publications investigating and/or defending its status (e.g. O'Grady 1906, Stoy 1907, Milner-Barry 1908, Isaacs 1917, Ernst 1918, Saunders 1919-20, Board of Education 1929). The 1912 Circular on Modern Languages (Board of Education Circular 797) already noted with concern that German "was completely disappearing from the curriculum in schools where it formerly found a place" (cited by Phillips \& Filmer-Sankey 1993: 12), a development that was only exacerbated by the impact of World War I. In 1918, 65 of the most important private schools still taught German, but between 1912 and 1918, 38 schools had given it up as a subject (though 13 of them in the two years before the war). In 1908, according to a report in Modern Language Teaching (1908), 40.4\% of schools had offered German, but this sank steadily to $27.3 \%$ in 1929 ; in this year, of 48 counties, 17 offered no German at all; ditto in 18 of 79 boroughs (Ortmanns 1993: 95-96). In her "Plea for the Study of German", Marion Saunders noted in 1919-20 that there had certainly been a reaction against German after the outbreak of war (Saunders noted falls of $26 \%$ and $18 \%$ in two large, but unnamed, girls' schools between 1914 and 1919); Saunders pointed out that this reaction was exacerbated by the shortage of teachers as many German nationals had to leave England, "and their places were only slowly filled by British-born teachers"11 (Saunders 1919-20: 177). In addition to the dismal figures for German in secondary schools, Saunders also noted that the common Public Schools examination for the preceding year had included no German paper, indicating that it was barely being taught in preparatory schools; at Sandhurst there was "not a solitary cadet" learning German, and only $12 \%$ of naval cadets at the Royal Navy College Osborne (Saunders 1919-1920: 178-179).

For her readers in the German journal Monatshefte für deutsche Sprache und Pädagogik Ernst (1918) assembled extracts from correspondence to Modern Language Teaching over the years 1914-1917 on the question of whether or not learning German, "the language of the enemy", should be encouraged; perhaps unsurprisingly, given Ernst's audience, the majority of space is given to those arguments made in favour of German, but the range of arguments presented - albeit anecdotally - is typical of discussions of the period. It was generally acknowledged that German was "useful" - in commerce, for scientific purposes, and (still) as the language of an important European state - even if voices were now also making similar cases for Russian and Italian. German history and literature were also still generally acknowledged to be worthy of study; if some voices considered their study "detrimental" or "unwholesome" (Ernst 1918: 110), others felt the risk could be overcome by making sure teachers were British. Opinion was divided between those who acknowledged the importance of German but felt that one should not pay one's enemy the compliment of taking note of their culture, and those who, on the contrary, emphasized both the dangers of being ignorant of one's enemy (or political and commercial rival) and so of not being able to compete with Germany on equal terms, and the foolishness of dismissing an entire cultural tradition because of current antagonisms.

Despite such reasoned voices, a decision recorded in the minutes of the Masters' Meeting at Rugby of November 22, 1918, seems symptomatic of what was happening across the country in the second decade of the $20^{\text {th }}$ century: in Upper Middle 1 , "German will be dropped, two of the periods being devoted to Latin and two to French". While German did not completely disappear from Rugby, it lost ground to French; Latin 
remained secure because it was still a requirement for university admission. ${ }^{12}$ By 1929 , only 8 of 512 schools teaching a foreign language were offering German; another report stated that in 1925-26, of 1250 grant-aided schools (i.e. private schools that received some government funding), 872 provided only French; in 1928 at the Secondary School Certificate examination, when 54,273 students offered French, only 3,837 offered German (Spanish, with 719 entrants, was small but growing) (Phillips \& Filmer-Sankey 1993: 15-16). In Ireland, only 7.4\% of examination candidates took German in 1919 (down from the high-point of $18.4 \%$ in 1912); in 1927 there were only 33 candidates (Fischer 2000: 465-466). ${ }^{13}$

The 1918 Leathes Report on Modern Languages stated that there was no reason why French should always be the first foreign language, although it nevertheless de facto accepted the pre-eminence of French in schools and universities. The report made the case - as had the earlier 1912 Circular - that at least some schools should make German the first foreign language, especially in regions where commercial and industry links to Germany were strong, echoing the kind of arguments collated by Ernst (1918): "After the war, the importance of German must correspond with the importance of Germany. If Germany after the war is still enterprising, industrious, highly organized, formidable not less in trade than in arms, we cannot afford to neglect her or ignore her for a moment" (Leathes 1918: 61, cited by Ortmanns 1993: 225). The report also pointed out that other languages should not be neglected either, but its ambitious proposals for supporting the four "other" European languages (German, Spanish, Italian and Russian) were, in the face of severe budget cuts in 1922, never implemented (Bayley 1991: 19). Still, some universities did extend the range of modern languages, and "at last European languages other than French and German began to emerge as university subjects" (Bayley 1991: 18).

\section{LOTF (Languages Other Than French) in the $20^{\text {th }}$ century}

In essence, the pre-eminence of French, when the case was only ever being made for the importance of learning one foreign language, set the points for the rest of the twentieth century. Repeated efforts in official and subject association reports and initiatives to promote what came to be known as LOTF (Languages Other Than French, the very invention of such an acronym speaks volumes) did not greatly change the situation. The title of the study by Phillips \& Filmer-Sankey (1993), Diversification in Modern Language Teaching, might equally be - as far as its historical chapters are concerned - Rather Little Diversification in Modern Language Teaching. Over and over again in the first half of the twentieth century, reports on modern languages earnestly pointed out that there was no reason why German should not be taught as the first foreign language in some schools at least, from the 1912 Circular 797, to the Leathes Report of 1918, to the 1929 report on the Position of German in Grant-Aided Secondary Schools in England (Board of Education 1929), to the Norwood Report of 1941 and a 1949 report by the Incorporated Association of Assistant Masters (Ortmanns 1993: 92-94; Phillips \& Filmer-Sankey 1993: 12-19). By the second half of the century, small steps were being taken in the direction of diversification. In some schools, year groups alternated from year to year between starting either French or German as a first foreign language (Sidwell 1976: 26; Reeves 1986: 10); and although Sheppard \& Turner 
lamented in 1976 that "only" 16 of 70 secondary schools in Norfolk offered German as the first foreign language (1976: 15), that was probably quite an advance.

From the late 1920s onwards (perhaps as the public view of Germany came closer the picture of post-war Germany conjured up by the Leathes Report, cited above), German grew again in popularity, both measured against the overall number of candidates and compared to other foreign languages (Ortmanns 1993: 101). At the Second Certificate Examination (taken by about $10 \%$ of pupils only), German had been taken by only 90 candidates in 1920, but this jumped to nearly 900 by 1938 (Ortmanns 1993: 100-101, 103). The resurgence appears to be reflected in the number of textbooks in my working bibliography, which contains well over 100 new titles published in the 1930s, compared to just over 30 for the 1920 s. $^{14}$

\section{Conclusion}

The history of French and German in British schools is arguably a case study for the power of structural inertia. French entered school curricula as the first foreign language, and has never really wavered from that position. German, as the second language, has, however, been more vulnerable to changes in social attitudes and in policy (and has now ceded its position to Spanish). Since 2004 a whole generation of pupils, in state schools especially, have not had to take a language other than English to 16 at all, and at the same time the economic case is energetically being made not just for German and Spanish but also for 'new' languages like Chinese. Whether even these upheavals will be enough to shake the primacy of French in British education remains to be seen.

\section{BIBLIOGRAPHIE}

ARNOLD, E.P. \& WAREN, FABIAN (1900). "The teaching of modern languages in preparatory schools." In Board of Education (ed.). Special Reports on Educational Subjects, vol. 6: Preparatory Schools for Boys: Their Place in English Secondary Education. Presented to both Houses of Parliament by Command of Her Majesty, Cd. 418. London: H.M.S.O., 231-247.

ATKINS, Henry Gibson (1905). German exercises: specially arranged to accompany the Skeleton German grammar. London: Blackie \& Son.

BALLY, Stanislas E. (1896). A manual of German commercial correspondence (Methuen) (following his similar manual for French, published 1894). London: Methuen.

BAYLEY, Susan (1989). “'Life is too short to learn German': Modern languages in English elementary education, 1872-1904”. History of Education, 18, 57-70.

BAYLEY, Susan (1991). “Modern Languages: An 'Ideal of Humane Learning': The Leathes Report of 1918”. Journal of Educational Adminstration and History, 23, 11-24. 
BENSON, A.C. (1907). "The place of modern languages in the secondary curriculum. Presidential Address to the Modern Language Association, Durham, January 4". Modern Language Teaching, 3, 6-18; also Journal of Education, 2, 117-121.

BERNAYS, Adolphus (1849). On the German Language. Introductory Lectures delivered at Queen's College, London. London: n.p.

BISCHOFF, Dietrich (1939). "Deutsch und französisch im britischen Bildungswesen unter besonderer Berücksichtigung der Entwicklung in Schottland”. Internationale Zeitschrift für Erziehung, 8, 180-202.

BOARD OF EDUCATION (1912). Circular No. 797. Modern languages (re-issued 1925).

BOARD OF EDUCATION (1928a). The Position of French in the First School Certificate Examinations. (Educational Pamphlet, $\mathrm{n}^{\circ} .70$ ).

BOARD OF EDUCATION (1928b). Report on the Position of French in the First School Certificate Examinations. London: H.M.S.O.

BOARD OF EDUCATION (1929). Position of German in Grant-Aided Secondary Schools in England. (Educational Pamphlets, $\mathrm{n}^{\circ}$. 77.) London: H.M.S.O.

BOARD OF EDUCATION (1930a). Memorandum on the Teaching of Foreign Languages in Certain Types of Schools. (Educational Pamphlets, $\mathrm{n}^{\circ}$. 82.) London: H.M.S.O.

BOARD OF EDUCATION (1930b). Second Interim Report of the committee of education for Salesmanship. Modern Languages. London: H.M.S.O.

BOEHNING, John (1977). The Reception of Classical German Literature in England. A documentary history from contemporary periodicals, 1760-1860, 10 vol. New York / London: Garland.

BRERETON, Cloudsley, SAVORY, D.L., RIPPMANN, Walter \& KIRKMAN, F.B. (1908). "Report on the conditions of modern (foreign) language instruction in secondary schools". Modern Language Teaching, 4, 33-38, 65-68.

BREUL, Karl (1897). “Großbritannien”. In A. Baumeister (ed.). Handbuch der Erziehungs- und Unterrichtslehre für höhere Schulen. München: Beck, 737-892.

BREUL, Karl (1899). The Teaching of Modern Foreign Languages in Secondary Schools. Cambridge: Cambridge University Press.

BRIDGE, George Fletcher (1921). "French and German in Higher Education“. Contemporary Review, 120, 805-810.

BRONTË, CHARLOTTE (1853 [2000]). Villette. Oxford: Oxford University Press, 2000.

BRYCE, James, et al. (1895). Report of the Commissioners on Secondary Education. London: H.M.S.O.

COLLINS, H. F. (1934). “Modern languages”. In E. Percy \& M.P. Former (ed.). The Yearbook of Education 1934. London: Evans, 417-428.

ERNST, Adolphine B. (compiler) (1918). "The status of German in Great Britain". Monatshefte für deutsche Sprache und Pädagogik, 19, 110-113.

EUGÈNE-FASNACHT, G. (1878). Macmillan's Progressive German Course. I. First Year. Containing easy lessons on the regular accidence. London: Macmillan.

EVE, Henry Weston (1880). A School German Grammar. London: Nutt.

FISCHER, Joachim (2000). Das Deutschlandbild der Iren 1890-1939. Heidelberg: Winter. 
FLOOD, John L. (2000). “German Studies and Collections since 1830”. In Graham Jefcoate, William A. Kelly \& Karen Kloth (ed.). Handbuch historischer Buchbestände in Europa. A guide to Collections of Books Printed in German-Speaking Countries before 1901 (or in German elsewhere) held by Libraries in Great Britain and Ireland. Vol. 10. Hildesheim: Olms, 28-33.

HARDACH-PINKE, Iris (2000). “German governesses in England”. In F. Bosbach, C. Filmer-Sankey \& H. Hiery (ed.). Prinz Albert und die Entwicklung der Bildung in England und Deutschland im 19. Jahrhundert (= Prince Albert and the development of education in England and Germany in the $19^{\text {th }}$ century). München: Saur, 23-32.

HAWKINS, Eric (1987). Modern Languages in the Curriculum. Revised edition. Cambridge: CUP. HOPE SIMPSON, J.B. (1967). Rugby since Arnold. A History of Rugby School since 1842. London: Macmillan.

IRELAND, A. V. (1935). A Quick-Reference German Grammar. London: Methuen.

ISAACS, Nora (1917). “The study of German after the war”. Modern Language Teaching, 13, 85-86. [also her letter in MLT, 13 (1917), 106.]

JOHNSON, Edward (1891). The Educational Annual, vol. 3. London: George Philip \& Son.

KIBBEE, Douglas (1991). For to Speke Frenche Trewely: The French Language in England, 1000-1600: Its Status, Description and Instruction. Amsterdam/Philadelphia: Benjamins.

LAMBLEY, Kathleen (1920). The Teaching and Cultivation of the French Language in England during Tudor and Stuart Times. Manchester: Manchester University Press / London: Longman.

LEATHER, C. H. (1932). Common Errors in German. London: Dent.

LEATHES, Stanley, et al. ( ${ }^{2} 1928$ [1918]. Modern Studies. Being the report of the Committee on the Position of Modern Languages in the educational system of Great Britain, Cmd 9036 (Leathes Report), 1928.

LENTZ, E. Ernest (1945). A German vocabulary: the 3500 most useful words arranged in connected groups suitable for translation, conversation, and free composition in University Matriculation, Leaving Certificate, and similar examinations. London: Blackie.

MCLELLAND, Nicola (2012). "Walter Rippmann and Otto Siepmann as Reform Movement textbook authors: A contribution to the history of teaching and learning German in the United Kingdom". Language \& History, 55 (2), 125-145.

MCLELLAND, Nicola (in press, to appear 2015). German Through English Eyes. A History of Language Teaching and Learning in Britain, 1500-2000. Bristol: Multilingual Matters.

MCLELLAND, Nicola \& SMITH, Richard (2014). "Introduction: Building the history of modern language learning". In Building the History of Modern Language Learning. Special issue of Language \& History, 57 (1), 1-9.

MILNER-BARRY, E.L. (1908). “The position of German in English Schools”. Modern Language Teaching, 4, 68-81.

O'GRADY, Hardress (1906). “German?”. Modern Language Teaching, 2, 207-210.

ORTMANNS, Karl Peter (1993). Deutsch in Großbritannien. Die Entwicklung von Deutsch als Fremdsprache von den Anfängen bis 1985. Stuttgart: Steiner.

OTTO, Emil (1890). A German Conversation-Grammar. A Practical Method of Learning the German Language. Revised by Franz Lange. London: Nutt / Heidelberg: Groos. $25^{\text {th }}$ edition. With vocabulary. 
PAULIN, Roger (2010). "Breul, Karl Hermann (1860-1932)”. In Oxford Dictionary of National Biography, Oxford University Press, May 2010; [online edition, May 2011, accessed 19 Oct 2011. http://www.oxforddnb.com/view/article/61616].

PEGRUM, Arthur W. (1914). “The oral teaching of German”. Modern Language Teaching, 10, 206-212.

PHILLIPS, David, \& FILMER-SANKEY, Caroline (1993). Diversification in Modern Language Teaching: Choice and the National Curriculum. London / New York: Routledge.

PROESCHOLDT, C. W. (1991). "The introduction of German language teaching into England". German Life and Letters, 44, 93-102.

REEVES, Nigel B. R. (1986). "Why German”. In CILT (ed.). German in the United Kingdom: Issues and opportunities. London: CILT, 1-12.

[REPORT 1889:] "Report of the Local Examinations and Lectures Syndicate to the Senate of Cambridge University (Examination for Commerical Certificates), 1888”. In Cambridge Local Examination Commercial 1888-1894. Cambridge: Printed for the Syndics at the University Press, 5-12. Held in Cambridge University Library, Cam.c.11.51.10.

[REPORT 1894:] "Report of the Committee Appointed to Enquire into the Entrance Examinations (in non-military subjects) of Candidates for Commissions in the Arma (1894)". Presented to both Houses of Parliament by Command of Her Majesty, C-7373, London: H.M.S.O.

[REPORT 1911:] "Report of the Report of the Local Examinations and Lectures Syndicate to the Senate of Cambridge University", 1911, fold-out table. Held in Cambridge University Library, Cam.c.11.51.54.

RJÉOUTSKI, Vladislav, ARGENT, Gesine \& OFFORD, Derek, eds. (2014). European Francophonie: The Social, Political and Cultural History of an International Prestige Language. Frankfurt: Lang.

RIPMAN (= RIPPMANN), Walter, ALGE, Sines \& HAM-BURGER, Sophie (1917 [ $\left.\left.{ }^{1} 1899\right]\right)$. Dent's new first German book. New York: Dutton.

RIPPMANN, Walter (1899). Hints on teaching German, with a running commentary to Dent's First German Book and Dent's German Reader. London: Dent.

SAUNDERS, Marion J. (1919-20). “A plea for the study of German”. Modern Languages, 1, 177-179.

[SCHEDULE 1869:] "Schedule of Examination for Women 1869 sanctioned by GRACE of the SENTATE October 29, 1868”. In Cambridge Higher Local Examination Papers 1869-1883. Cambridge University Library Cam.c.11.51.27, 4.

SHEPPARD, R. and TURNER, G. (1976). “ A regional view”. In CILT (ed.). German in the United Kingdom. Problems and Prospects. CILT: London, 14-17.

SIDWELL, Duncan M. (1976). “An LEA [Local Education Authority] perspective”. In CILT (ed.). German in the UK: problems and prospects. London: CILT, 23-26.

SIEPMANN, Otto ( ${ }^{2} 1900$ [11896]). A Public School German Primer comprising a first reader, grammar, and exercises, with some remarks on German pronunciation and full vocabularies. London / New York: Macmillan.

SIEPMANN, Otto (1902). "Letter to his son Harry Siepmann, dated $6^{\text {th }}$ February 1902". In Letters, vol. 1902-1904, One of six volumes of letters by Otto Siepmann donated to NM by the greatgrandson of Otto Siepmann, Harry Siepmann. 
SIEPMANN, Otto (1912). A primary German course comprising object lessons, a first reader, grammar and exercises, with some remarks on German pronunciation and the relation between German and English and full vocabularies. London / New York: Macmillan.

STERN, Hans Heinrich (1983). Fundamental Concepts of Language Teaching. Oxford: Oxford Uuniversity Press.

STOCKTON, Charles E. (1936). School Certificate German Composition. London: Methuen.

STOY, J.F. (1907). "The place of German in the curriculum of secondary schools". Modern Language Teaching, 3, 146-149.

TRECHMANN, Emil (1899). Passages for Translation into French and German for use in University and school classes Owned by Trechmann. Sydney: Angus \& Robertson.

TROTTER, J. J. (1898). Object Lessons in German. Based on "Object Lessons in French" by Alec Cran. Illustrated. London-Edinburgh-New York: Thomas Nelson and Sons, 1898. Mit deutschenglischem Wörterverzeichnis.

TUMBER, Margaret A. (1986). “German as first foreign language”. In CILT (ed.). German in the United Kingdom: issues and opportunities. London: CILT, 44-47.

USHER, H. J. K., BLACK-HAWKINS, C.D. \& CARRICK, G.J. (1981). An Angel without Wings. The history of University College School 1830-1980. London: University College School.

WATSON, Foster (1971 [1909]). The Beginnings of the Teaching of Modern Subjects in England. London: Pitman. Reprint Wakefield: S.R. Publishers.

WENDEBORN, Gebhard Friedrich August (1774). The elements of German grammar. London: printed for C. Heydinger

WHITEHEAD, Maurice (2004). “Siepmann, Otto (1861-1947)", Oxford Dictionary of National Biography, Oxford University Press, 2004; [online edition, Oct. 2009, accessed 27 June 2011. http:// www.oxforddnb.com/view/article/36088].

\section{NOTES}

1. On the status and teaching of French in England, 1000-1600 (Kibbee 1991), and, for the teaching of French in Tudor and Stuart times, Lambley (1920). The history of language learning in Britain is still very little studied. For a brief overview of work done to date (McLelland \& Smith in prep.); McLelland (in press, to appear 2015) provides a history of German teaching and learning which also gives an insight into developments in modern language education more generally since 1600 . Watson's survey of the Beginnings of Modern Subjects in England (1909) includes sections on the modern languages, and was, as was still noted in the 1971 reprint, "the basic source work [...] yet to be superseded" (p. v). Amongst (somewhat) more recent work, the survey by Hawkins (1987) is the closest to an overview of the history of modern language teaching for the British context, and is particularly useful for its discussion of the late nineteenth-century reform movement and its limited impact on teaching (Hawkins 1987: 117-153). Ortmanns (1993) deals specifically with the history of German teaching in Great Britain up to the year 1985 and is an invaluable source of facts and figures.

2. Examinations were offered at two levels, for those under the age of 16 (Junior), and for those under the age of 18 (Senior). Similar examinations were introduced by the University of Oxford Delegacy of Local Examinations in the same year. Besides these boards, there were also the College of Preceptors examinations, the University of London examinations and others (Bayley 
1989: 15). The College of Preceptors (since 1998 the College of Teachers) was established by Royal Charter in 1849; it was one of the first bodies to provide formal examinations for pupils, from 1851 (as well as for teachers, from 1846).

3. The student body at higher grade schools would usually consist of "a few pupils from well-off families, the rest from the ranks of skilled workers, minor professionals, and tradesmen" (Bayley 1989: 59).

4. Ortmanns (1993: 140-143) presents modest evidence of teacher and pupil exchange in Britain, particularly the Exchange of Assistants scheme established between France, Germany and Britain from 1904.

5. It is worth noting that a similar text published thirty years later (though aimed at School Certificate rather than university level) claimed to be suitable for practice in French, German or Spanish. Spanish had a marginal existence in schools for decades (Tables 1 and 2 above; and we saw earlier that an 1897 report found that out of 794 secondary schools of various types, only 6 taught Spanish (and 4 Italian, 217 German, 345 French). The Leathes Report of 1918 (part of a wide-ranging investigation of education for the Board of Education, with companion reports on the natural sciences, English and the Classics) had argued that Spanish was (or should be) important for commerce; Italy was a "pillar of European civilization" (Bayley 1991: 14). At overseas (colonial) examination centres for the Cambridge Junior examinations, candidates for Spanish (and indeed Dutch) outnumbered those for German in 1911 already (Report 1911). Spanish overtook German as the second foreign language at age 16 in Britain in the first decade of the $21^{\text {st }}$ century.

6. Translation NM. The original reads: „[...]denn auf den klassischen Sprachen beruht Deine Zukunft. In Rugby wirst Du allerdings auch im Deutschen und im Französischen geprüft, aber das Lat. u. Griech. bilden die Hauptsache."

7. Previously, the Classics had enjoyed double weighting. The situation was the same in Ireland (Fischer 2000: 463).

8. I follow the account of Bayley (1991: 13).

9. On the Leathes Report, also Byram in this volume.

10. In universities, however, German was better provided for than the proportions in schools might have led one to expect: the Leathes Report of 1918 found that among 22 universities, 146 individuals were involved in teaching modern foreign languages, and if nearly half of them taught French (70, plus another five responsible for French and German), there were at least over a quarter (42) devoted to German (Bayley 1991: 14).

11. Also Ortmanns (1993: 116). Like Saunders, Ortmanns (1993: 116) suggests that the drop-off in numbers during the war might have less to do with aversion to German, and more to do with the availability of teachers, who were involved in the war itself.

12. Cambridge did not drop the requirement for one of Greek or Latin until 1960, thereafter requiring instead any two languages (dropped to one in 1967). The requirement for foreign languages was dropped entirely by universities from the late 1960 s onwards.

13. There are interesting gender differences here. From 1933 to 1945, the number of boys taking German examinations sank and remained under 30; but in 1936 there were 134 girls taking the examinations, all coming from five convent schools. As noted above, Fischer finds that in Ireland German was a subject for girls from the outset.

14. The first decade of the $20^{\text {th }}$ century saw about 70 titles, as the professionalization of language teaching and the reform movement took root; the 1960s (the era of the 'languages for all' movement) and the 1990s (a time of increased interest in Germany after unification in 1990, at a time when one language was still compulsory to age 16, no longer the case since 2004) similarly saw highpoints of over 70 titles. 


\section{RÉSUMÉS}

This article outlines the status of French and German in British education from the 1850s, when they were introduced as subjects in public examinations, to the 1930s, with a few remarks on the period thereafter, with reference to contemporary reports as well as to textbooks used in the period. It touches on differences in the status of French and German in the education of boys and girls in the $19^{\text {th }}$ century, and on the question of who taught French and German in these early decades. Throughout the period, French was the first foreign language, with German a clear second, and German came under particular pressure in the early decades of the $20^{\text {th }}$ century as even proponents of Modern Languages argued that most pupils needed only to learn one language; World War I also had a negative impact. Concerted efforts were made from about 1912 onwards to stress that French should not always be the first language taught, and these began to have some effect in the second half of the $20^{\text {th }}$ century, but German always remained a clear second (and has now been overtaken by Spanish as second foreign language in the $21^{\text {st }}$ century).

\section{INDEX}

Keywords : enseignement des langues étrangères, XIXe siècle, XXe siècle, français langue étrangère, allemand langue étrangère, langues modernes en Grande-Bretagne, choix des langues, politique des langues étrangères, pédagogie de l'éducation des filles, Leathes Report

Mots-clés : foreign language teaching, 19th century. 20th century, French as a foreign language, German as a foreign language, modern languages in Great Britain, language choice, foreign language policy, gender-specific pedagogy, Leathes Report

\section{AUTEUR}

\section{NICOLA MCLELLAND}

Universite of Nottingham, England

Nicola.McLelland@nottingham.ac.uk 